\title{
BUDAYA TERTIB BERLALU-LINTAS "KAJIAN FENOMENOLOGIS ATAS MASYARAKAT PENGENDARA SEPEDA MOTOR DI KOTA BANDUNG"
}

\author{
Oleh: Soni Sadono \\ Fakultas Industri Kreatif, Telkom University \\ Jl. Telekomunikasi No. 1, Ters. Buah Batu, Bandung Edupark-Teknoplex, Bandung \\ E-mail: sonisadono66@gmail.com
}

\begin{abstract}
Intisari
Lemahnya kesadaran masyarakat terhadap peraturan berlalu-lintas terlihat dari rendahnya tingkat kedisiplinan masyarakat dalam berkendara, sehingga melahirkan budaya tidak disiplin pada masyarakat. Kurang sadarnya masyarakat dalam hukum berlalu-lintas dapat dilihat dalam perilaku seperti semakin meningkatnya pelanggaran lalu lintas oleh pengendara motor. Hal tersebut dapat diketahui dari banyaknya pelnggaran rambu lalu lintas di kota Bandung pada tahun 2014 dengan jumlah 39.205 pelanggaran (Sumber: Polwiltabes Kota Bandung, 2015). Perilaku ketidakdisiplinan masyarakat dalam berlalu-lintas seperti mengendarai kendaraan melebihi batas kecepatan yang ditentukan, menerobos lampu lalu lintas, melewati marka pembatas jalan, tidak melengkapi alat keselamatan seperti halnya tidak menggunakan helmet, spion, lampu-lampu kendaraan, ketidaklengkapan surat-surat kendaraan bermotor, tidak taat membayar pajak, menggunakan kendaraan tidak layak pakai. Pelanggaran lalu lintas yang sering terjadi juga melibatkan cara pengendara yang "menerabas antrian kendaraan, berkendara zigzag dengan kecepatan tinggi, beberapa kali pernah menerabas lampu lalu lintas, dan melanggar rambu yang dilarang menikung” (Hendratno, 2009: 499). Jurnal ini berupaya untuk menjelaskan secara literatur dan field research terhadap permasalahan budaya tertib berlalu-lintas, dengan pendekatan kualitatif.
\end{abstract}

Kata kunci: Budaya Berlalu-Lintas, Sikap Disiplin, Fenomenologis.

\begin{abstract}
In the text, relations between humans, religions and culture be in the same room. With religiousness, religion is in the form of human civilization, including culture as the product of religion. Therefore the relationship between religion and culture as fundamental absence of relationship. For communities cultural of Java society, the fasting month or Ramadhan is a sacred and sacralmonth. Those who to Islam, they prepared of judges the physical condition and spiritual through the tradition of Sadranan or Nyadran. This tradition is a hereditary, following the Java calendar. Preservation of the cultural is interesting to be researched further through the two dimensions of God perspective, religions and culture. Nyadran, is the mixing of religious traditions and culture. This research using Heritere la Culture Theory as amplifier argumentation. The theory states that the contribution of culture should be passed down from generation to generation, and must be the same without any change in the ritual. This study, builds upon the system of semiotics. In pragmatics, semiotics parse on the origin of the sign of the Godhead in the rituals of Nyadran, by the sign of the usefulness of the implementing Nyadran, and propaganda signs to interpreted, with subjective behaviour.
\end{abstract}

Keywords : Semiology, Heritere la Culture Theory, Culture, Sadran. 


\section{A. PENDAHULUAN}

Dewasa ini, kondisi sarana angkutan umum yang belum memadai membuat masyarakat lebih memilih untuk membeli kendaraan pribadi sebagai sarana transportasi, dari pada harus menggunakan sarana transportasi umum sebagai alat mobilitas dalam menunjang kehidupan masyarakat. Pernyataan tersebut apabila dilihat dari sisi sosial budaya, keinginan seseorang untuk memiliki kendaraan pribadi sedikit banyak dipengaruhi adanya pandangan bahwa memiliki kendaraan bermotor mencerminkan status sosial di masyarakat (Hendratno, 2009: 449).

Hal tersebut terlihat dari perkembangan transportasi darat dari tahun ke tahun selalu meningkat terutama transportasi kendaraan roda dua (sepeda motor) (Maspupa, 2014: 3). Meningkatnya penggunaan sepeda motor, juga dipengaruhi oleh beberapa faktor, yaitu: (1) harga minyak mentah yang mempengaruhi harga bahan bakar minyak (BBM) di Indonesia sejak tahun 2005.

Ketika harga BBM tidak menentu, masyarakat cenderung akan memilih kendaraan yang hemat BBM. (2) Lamanya waktu yang dibutuhkan untuk mencapai tujuan. (3) Mahalnya harga tarif angkutan umum yang tidak sebanding dengan keamanan dan kenyamanan bagi penggunanya (Yogatama, 2013: 2). Akan tetapi, kepemilikan kendaraan pribadi tersebut tidak disertai dengan tingkat disiplin dalam berkendara pada masyarakat.

Lemahnya kesadaran masyarakat terhadap peraturan berlalu-lintas terlihat dari rendahnya tingkat kedisiplinan masyarakat dalam berkendara, sehingga melahirkan budaya tidak disiplin pada masyarakat. Kurang sadarnya masyarakat dalam hukum berlalu-lintas dapat dilihat dalam perilaku seperti semakin meningkatnya pelanggaran lalu lintas oleh pengendara motor. Hal tersebut dapat diketahui dari banyaknya pelnggaran rambu lalu lintas di Kota Bandung pada tahun 2014 dengan jumlah 39.205 pelanggaran (Sumber: Polwiltabes Kota Bandung, 2015).

Perilaku ketidakdisiplinan masyarakat dalam berlalu-lintas seperti mengendarai kendaraan melebihi batas kecepatan yang ditentukan, menerobos lampu lalu lintas, melewati marka pembatas jalan, tidak melengkapi alat keselamatan seperti halnya tidak menggunakan helmet, spion, lampu-lampu kendaraan, ketidaklengkapan surat-surat kendaraan bermotor, tidak taat membayar pajak, menggunakan kendaraan tidak layak pakai.

Pelanggaran lalu lintas yang sering terjadi juga melibatkan cara pengendara yang "menerabas antrian kendaraan, berkendara zigzag dengan kecepatan tinggi, beberapa kali pernah menerabas lampu lalu lintas, dan melanggar rambu yang dilarang menikung” (Hendratno, 2009: 499).

Permasalahan tersebut sampai saat ini selalu dihadapi oleh para penegak hukum. Hal itu sudah dianggap biasa dan menjadi kebiasaan masyarakat. Tatkala para pengguna kendaraan di Indonesia dibandingkan dengan negara-negara maju yang secara keseluruhan sudah mampu menciptakan budaya disiplin dalam tatanan kehidupan. Hal tersebut yang menjadikan titik tolak pentingnya menciptakan budaya disiplin sebagai penunjang dalam meningkatkan kebermaknaan kehidupan sosial.

Keadaan masyarakat yang seperti itu dijelaskan sesuai dengan yang digambarkan Chapin (1974: 9). 
Diterbitkan oleh Program Studi Ilmu Komunikasi

Universitas Ahmad Dahlan Yogyakarta

What individuals actually do in their daily routine is the result of a complex and variable mix of incentives and constraints serving to mediate choice, often functioning in differentially lagged combination, with some activities directly traceable to positive choice, and some attributable to negative choice in the sense that constraints over shadow opportunities for choice.

Kondisi lain digambarkan Emile Durkheim (Hendratno, 2009; Merton, 1967), perilaku kendaraan seperti di atas, diistilahkan sebagai anomie, berpudarnya pegangan pada kaidah-kaidah yang ada menimbulkan keadaan yang tidak stabil, dan keadaan tanpa kaidah. Perilaku menyimpang (deviant behavior) terjadi apabila manusia mempunyai kecenderungan untuk lebih mementingkan suatu nilai sosial budaya, daripada kaidah-kaidah yang ada untuk mencapai cita-cita atau kepentingan.

Banyak permasalahan yang timbul dengan lemahnya budaya disiplin pada masyarakat, yang pelanggarannya dalam berlalu-lintas kerap terjadi, pertikaian sesama pengguna jalan, saling adu mulut, dan yang paling fatal munculnya korban jiwa akibat ketidaksiapan para pengguna jalan dalam memahami peraturan lalu lintas.

Terjadinya pelanggaran lalu lintas salah satunya didasari oleh keberanian untuk melanggar karena adanya mentalitas bahwa setiap masalah dapat diselesaikan secara "damai" dengan Polantas, adanya budaya menerabas dan pudarnya budaya malu bahkan bagi sebagian orang menjadi kebanggan tersendiri apabila dapat mengelabui Polantas atau melanggar rambu-rambu lalu lintas (Hendratno, 2009: 501).

Pernyataan tersebut dibenarkan dengan hasil penelitian yang dilakukan oleh Hadiluwih (2006: 141) yaitu sikap mental dan disiplin pengguna jalan raya serta petugas lalu lintas kurang terpuji sehingga muncul ketidakpatuhan yang diyakini dapat diselesaikan dengan uang. Berdasarkan hasil penelitian yang dilakukan Akbarto di Malang tahun 2009, dari 50 responden terdapat 28 responden (56\%) menyatakan pernah melakukan suap pada Polantas guna damai di tempat. Suap dilakukan dengan terang-terangan (67,9\%), dan sembunyi-sembunyi $(32,1 \%)$.

Alasan untuk menyuap petugas sebab mudah $(25 \%)$, cepat $(71,4 \%)$, dan murah $(3,6 \%)$. Mayoritas alasan melakukan suap terhadap Polantas karena cepat dibandingkan penyelesaiannya dengan perundang-undangan. Hal tersebut tentu saja menjadi indikasi bahwa masih banyak penyimpangan dan tindakan oknum polisi yang terjadi akibat budaya kerja belum berjalan sebagaimana mestinya (Zam, 2013: 89).

Pasal 106 ayat (1) menyebutkan bahwa "setiap orang mengemudikan kendaraan bermotor di jalan wajib mengemudikan kendarannya dengan wajar dan penuh konsentrasi". Selanjutnya dalam Pasal 283 disebutkan bahwa setiap orang yang mengemudikan kendaraan bermotor di jalan secara tidak wajar dan melakukan kegiatan lain atau dipengaruhi oleh suatu keadaan yang mengakibatkan gangguan konsentrasi dalam mengemudi di jalan.

Sebagaimana Pasal 106 ayat (1), dipidana dengan pidana kurungan paling lama tiga bulan kurungan atau denda paling banyak $\mathrm{Rp} 750.000,00$ (tujuh ratus lima puluh ribu rupiah). Namun, masih banyak pengendara roda dua yang melakukan kegiatan-kegiatan yang dilarang tersebut seperti menggunakan handphone.

Selain karena sarana dan prasarana, timbulnya kemacetan yang terdapat di kotakota besar diakibatkan bertambahnya jumlah kendaraan yang menjadi pemicu pengendara 
untuk melakukan pelanggaran. Misalnya kendaraan roda dua yang menggunakan trotoar sebagai jalan pintas karena jalan utama macet dan sebagainya. Hal yang memerlukan perbaikan demi ketertiban dalam lalu lintas yaitu sarana dan prasarana lalu lintas yang masih terbatas, menajemen lalu lintas yang belum berfungsi optimal, pelayanan angkutan umum penumpang yang belum memadai dan disiplin pemakai jalan yang masih rendah (Budiarto dan Mahmudah, 2007: 6).

Kota Bandung merupakan salah satu kota besar yang menjadi pusat tujuan wisata baik wisatawan lokal maupun mancanegara. Hal tersebut tentu saja mengundang semakin padatnya volume kendaraan terlebih menjelang hari-hari libur. Pada saat yang bersamaan kerawanan untuk terjadinya kecelakaan akan semakin besar. Semakin lemahnya masyarakat dalam taat berkendara membawa masyarakat Kota Bandung memiliki budaya yang buruk dalam berlalu-lintas, terbukti dengan semakin banyaknya pelanggaran-pelanggaran dan masyarakat menilai pelanggaran tersebut hal yang biasa dan lumrah adanya. Dengan demikian, dapat diasumsikan bahwa budaya disiplin masyarakat Kota Bandung dalam berkendara masih sangat kurang.

Untuk itu, jurnal ini berupaya untuk menguraikan dua hal utama. Pertama, bagaimanakah pengalaman berlalu-lintas kendaraan roda dua di Kota Bandung, tentu dilihat dari sudut pandang Fenomenologis? Kedua, bagaimana internalisasi disiplin dalam berlalu-lintas kendaraan roda dua perlu diberikan di Kota Bandung? Ketiga, bagaimana model internalisasi disiplin dalam berlalu-lintas kendaraan roda dua di Kota Bandung?

\section{B. KAJIAN PUSTAKA}

\section{Penelitian Terdahulu}

Permasalahan mengenai lalu lintas di Indonesia secara umum meliputi pandangan dari segi keamanan dan keselamatan para pengguna jalan raya, hal tersebut menjadikan permasalahan lalu lintas sebagai hal yang harus segera dibenahi, melihat kondisi sekarang, lemahnya budaya disiplin dalam berlalu-lintas masyarakat masih sangat rendah. Berdasarkan penelitian Anggarasena (2010: 84) yang berjudul "Strategi Penegakan Hukum Dalam Rangka Meningkatkan Keselamatan Lalu Lintas dan Mewujudkan Masyarakat Patuh Hukum", disebutkan kecelakaan lalu lintas di Indonesia dapat digambarkan dari data dalam kurun waktu 10 tahun terakhir menunjukkan bahwa kecelakaan lalu lintas yang terjadi di Indonesia telah merenggut korban jiwa rata-rata 10.000 per tahun.

Penyebab kecelakaan yang terjadi khususnya di kota-kota besar $86 \%$ didominasi oleh faktor manusia, sedangkan kendaraan $6 \%$, faktor jalan 5,5\% dan faktor lingkungan $2,5 \%$. Kecelakaan lalu lintas dapat juga disebabkan terjadinya pelanggaran lalu lintas oleh pengguna jalan seperti tidak mentaati rambu-rambu lalu lintas, tidak safety riding (helm atau sabuk pengaman) ketika berlalu-lintas, menggunakan kecepatan yang terlalu berlebihan dalam berkendaraan, dan lain sebagainya.

Sementara itu, upaya yang dilakukan oleh pihak-pihak yang terkait dalam rangka mewujudkan kepatuhan hukum masyarakat terhadap undang-undang lalu lintas belum menunjukkan kesungguhan yang berarti. Hal tersebut terlihat dari lemahnya langkah-langkah sosialisasi undang-undang lalu lintas sehingga tidak dilaksanakan dengan sebaik-baiknya". 
Diterbitkan oleh Program Studi Ilmu Komunikasi

Universitas Ahmad Dahlan Yogyakarta

Berdasarkan penelitian sebelumnya yang dilakukan Klavert (2007:57) yang berjudul "Kedisiplinan Berlalu-lintas Mengemudi Angkutan Kota Di Kota Semarang Ditinjau Dari Persepsi terhadap Penegakan Hukum Lalu Lintas", menyatakan bahwa terdapat keterkaitan antara disiplin berlalu-lintas dengan persepsi penegakan hukum dalam berlalu-lintas. Hal tersebut maksudnya, persepsi penegakan hukum yang pasti dapat merubah kedisiplinan dalam berlalu-lintas yang terjadi pada masyarakat saat ini. Sehingga dengan tegas dan sigapnya para penegak hukum dalam menindak para pengguna kendaraan bermotor yang tidak taat dengan peraturan lalu lintas akan membuat masyarakat menjadi disiplin dalam berlalu-lintas, kemudian menjadi suatu perilaku dan kebiasaan yang pada akhirnya memunculkan kebudayaan yang taat dalam berlalu-lintas.

Selain itu, penelitian yang dilakukan di Kota Pontianak yang dilakukan oleh Putra, Suni dan Hardilina (2013) menyebutkan bahwa kejelasan dan konsisten komunikasi Undang-Undang Nomor 22 tahun 2009 belum ditransmisikan dengan baik kepada mayarakat, masih banyak para pengguna jalan yang belum mengetahui ketentuan berlalu-lintas serta perilaku berlalu-lintas yang tertib dan aman. Sosialisasi baru sebatas pemberian informasi kepada masyarakat, tetapi belum mampu merubah kesadaran masyarakat atau menanamkan kesadaran kepada masyarakat agar dapat mematuhi dan melaksanakan budaya tertib berlalu-lintas. Dengan demikian, menurut Hendratno (2009), banyaknya masalah yang belum terselesaikan, seperti kemacetan dan infrastruktur yang buruk muncul dari perilaku masyarakat. Sehingga, masalah transportasi mesti dipecahkan melalui pendekatan sosialbudaya selain perbaikan fisik.

Matriks Posisi Penelitian

\begin{tabular}{|c|c|c|c|c|}
\hline $\begin{array}{c}\text { Nama } \\
\text { Peneliti }\end{array}$ & Tema/Topik & Sinopsis & Penelitian ini & Kebaruan \\
\hline $\begin{array}{l}\text { Bima } \\
\text { Anggarase } \\
\text { na (2010) }\end{array}$ & $\begin{array}{l}\text { Strategi } \\
\text { Penegakan } \\
\text { Hukum dalam } \\
\text { Rangka } \\
\text { Meningkatkan } \\
\text { Keselamatan } \\
\text { Lalu Lintas dan } \\
\text { Mewujudkan } \\
\text { Masyarakat } \\
\text { Patuh Hukum }\end{array}$ & $\begin{array}{l}\text { Berdasarkan penelitian } \\
\text { ini, diperoleh hasil } \\
\text { bahwa kecelakaan lalu } \\
\text { lintas di Indonesia } \\
\text { dapat digambarkan dari } \\
\text { data dalam kurun } \\
\text { waktu } 10 \text { tahun } \\
\text { terakhir, menunjukkan } \\
\text { bahwa kecelakaan lalu } \\
\text { lintas yang terjadi di } \\
\text { Indonesia telah } \\
\text { merenggut korban jiwa } \\
\text { rata-rata } 10.000 \text { per } \\
\text { tahun. Penyebab } \\
\text { kecelakaan yang terjadi } \\
\text { didominasi oleh faktor } \\
\text { manusia, kendaraan, } \\
\text { faktor jalan, dan factor } \\
\text { lingkungan. Maka untuk } \\
\text { tujuan menciptakan }\end{array}$ & $\begin{array}{l}\text { Penelitian ini lebih } \\
\text { menitikberatkan } \\
\text { pada } \\
\text { pembentukan } \\
\text { pembudayaan } \\
\text { dalam lalu lintas } \\
\text { yang dilakukan } \\
\text { pengendara, } \\
\text { penegak hukum } \\
\text { dan aturan hukum } \\
\text { itu sendiri }\end{array}$ & $\begin{array}{l}\text { Penelitian } \\
\text { tentang lalu } \\
\text { lintas yang } \\
\text { lebih } \\
\text { menekankan } \\
\text { pembudayaan } \\
\text { dalam diri } \\
\text { manusia } \\
\text { dalam } \\
\text { berkendara } \\
\text { melalui } \\
\text { pendidikan }\end{array}$ \\
\hline
\end{tabular}




\begin{tabular}{|c|c|c|c|c|}
\hline & & $\begin{array}{l}\text { masyarakat patuh } \\
\text { hukum guna } \\
\text { mewujudkan } \\
\text { Kamseltibcar Lantas } \\
\text { dibutuhkan suatu } \\
\text { strategi yaitu salah } \\
\text { satunya adalah } \\
\text { melaksanakan } \\
\text { manajemen dan } \\
\text { rekayasa lalu lintas } \\
\text { yang disesuaikan } \\
\text { dengan pendanaan } \\
\text { yang ada dan } \\
\text { menciptakan } \\
\text { penegakan hukum } \\
\text { yang lebih berorientasi } \\
\text { pada upaya merubah } \\
\text { situasi lalu lintas dalam } \\
\text { mewujudkan situasi } \\
\text { keamanan ketertiban } \\
\text { dan kelancaran lalu } \\
\text { lintas baik dari aspek } \\
\text { pengemudi, kendaraan, } \\
\text { jalan dan lingkungan. }\end{array}$ & & \\
\hline $\begin{array}{l}\text { Klavert } \\
(2007)\end{array}$ & $\begin{array}{l}\text { Keterkaitan } \\
\text { Antara Disiplin } \\
\text { Berlalu-lintas } \\
\text { Dengan } \\
\text { Persepsi } \\
\text { Penegakan } \\
\text { Hukum Dalam } \\
\text { Berlalu-lintas }\end{array}$ & $\begin{array}{l}\text { Persepsi penegakan } \\
\text { hukum yang pasti } \\
\text { dapat merubah } \\
\text { kedisiplinan dalam } \\
\text { berlalulintas yang } \\
\text { terjadi pada } \\
\text { masyarakat saat ini. } \\
\text { Sehingga dengan tegas } \\
\text { dan sigapnya para } \\
\text { penegak hukum dalam } \\
\text { menindak para } \\
\text { pengguna kendaraan } \\
\text { bermotor yang tidak } \\
\text { taat dengan peraturan } \\
\text { lalu lintas akan } \\
\text { membuat masyarakat } \\
\text { menjadii disiplin dalam } \\
\text { berlalu-lintas, kemudian } \\
\text { menjadi suatu perilaku } \\
\text { dan kebiasaan yang } \\
\text { pada akhirnya } \\
\text { memunculkan } \\
\text { kebudayaan yang taat } \\
\text { dalam berlalu-lintas. }\end{array}$ & $\begin{array}{l}\text { Penelitian tidak } \\
\text { hanya melihat } \\
\text { pada asepek } \\
\text { aparat penegak } \\
\text { hukum tetapi } \\
\text { semua hal yang } \\
\text { dapat membentuk } \\
\text { pembudayaan } \\
\text { dalam berlalu- } \\
\text { lintas }\end{array}$ & $\begin{array}{l}\text { Melihat semua } \\
\text { aspek } \\
\text { pembentuk } \\
\text { pembudayaan } \\
\text { dalam } \\
\text { berkendara }\end{array}$ \\
\hline
\end{tabular}


Diterbitkan oleh Program Studi Ilmu Komunikasi

Universitas Ahmad Dahlan Yogyakarta

\section{Etika Berlalu-Lintas}

Lalu lintas di dalam Undang-Undang Nomor 22 tahun 2009 Tentang Lalu Lintas Dan Angkutan Jalan didefinisikan sebagai gerak kendaraan dan orang di Ruang Lalu Lintas Jalan (Marzuki, 2009: 26). Transportasi jalan diselenggarakan dengan tujuan mewujudkan lalu lintas dan angkutan jalan dengan selamat, aman, cepat, lancar, tertib, dan teratur nyaman dan efisien, mampu memadukan moda transportasi lainnya, menjangkau seluruh pelosok wilayah daratan, untuk menunjang pemerataan, penggerak dan penunjang pembangunan nasional dengan biaya yang terjangkau oleh daya beli masyarakat (Kansil, 1995: 15).

Agar transportasi tersebut dapat digunakan sebagaimana mestinya, dibuatlah rambu lalu lintas untuk memberikan petunjuk mengenai mana yang boleh dan mana yang tidak boleh dilakukan selama berkendara. Rambu-rambu lalu lintas tersebut merupakan bagian dari perlengkapan jalan, yang dapat berupa lambang, angka, huruf, kalimat dan/atau perpaduan di antaranya sebagai peringatan, larangan, perintah atau petunjuk bagi pemakai jalan. Rambu-rambu tersebut digunakan untuk menyatakan perintah yang wajib dilakukan oleh pemakai jalan (Kansil, 1995: 185).

Menurut Baron \& Byrne (dalam Ayuningtyas dan Santoso, 2007: 5) kepatuhan merupakan bentuk dari pengaruh sosial, yaitu individu diminta untuk melakukan sesuatu dan individu tersebut pun melakukannya. Individu mematuhi suatu perintah karena figur yang memerintahkan memiliki otoritas tertentu (Deaux, Dane \& Wrightsman, 1993; Corsini, 2002: Bartoli, 2003). Figur otoritas tidak hanya individu, tetapi juga dapat berupa suatu aturan, seperti hukum, kitab suci dan rambu-rambu lalu lintas (Deaux, Dane \& Wrightsman, 1993: Corsini, 2002).

Berdasarkan penjelasan di atas, Soekanto (1980: 76) melihat bahwa dari sudut kepatuhan pemakai jalan raya, dibedakan dalam beberapa golongan. Pertama, Golongan yang mematuhi peraturan lalu lintas, golongan yang benar-benar memahami manfaat kaidah-kaidah hukum dan keserasian kaidah-kaidah hukum dengan nilai yang dianutnya. Kedua, golongan yang secara potensial merupakan pelanggar. Golongan ini tampaknya taat pada kaidah-kaidah hukum, tetapi kepatuhan itu sebenarnya sifatnya rapuh karena tergantung pada apakah penegakan kaidah-kaidah hukum diawasi atau tidak. Ketiga, golongan yang secara nyata melanggar hokum. Terhadap golongan ini diterapkan penjatuhan sanksi atau hukuman. Keempat, golongan bekas pelanggar. Golongan yang sudah pernah melanggar dan dikenai sanksi serta hukuman.

Watanabe (1995: 47) secara ekstrim menilai tinggi rendahnya disiplin nasional suatu bangsa diukur dari sejauh mana ketaatan masyarakat terhadap hukum lalu lintasnya di jalan raya. Pendapat Watanabe tersebut mengandung arti bahwa disiplin lalu lintas adalah cermin disiplin dan budaya bangsa (Tabah, 1991, 11-12).

Dari pemaparan di atas, penulis dapat menarik simpulan bahwa disiplin berkendara seseorang dipengaruhi oleh dua faktor yaitu faktor internal dan eksternal. Faktor internal dapat meliputi dorongan yang muncul dalam diri seseorang untuk mentaati peraturan lalu lintas, sementara faktor ekternal yaitu tekanan agar seseorang mentaati peraturan lalu lintas.

\section{Internalisasi Budaya Tertib}

Dalam beberapa pandangan, terdapat pengertian tentang pembudayaan. Salah satunya yang disampaikan oleh Naping dalam Rahman (2010: 71) menjelaskan bahwa pem- 
biasaan dapat dipahami sebagai pembudayaan (internalization) dan pelembagaan (institusialization).

Makna pertama merujuk pada upaya penanaman suatu nilai, sikap, perasaan, pandangan dan pengetahuan yang tumbuh dan berkembang dalam suatu masyarakat kepada individu-individu anggota kebudayaan bersangkutan. Sedangkan makna kedua menekankan pada aspek nilai, norma dan perilaku yang disepakati secara bersama oleh individu dalam suatu konteks sosial, mengendalikan dan mengarahkan perilaku untuk mencapai tujuan yang bersifat spesifik.

Huda (2009) menjelaskan bahwa proses pembudayaan merupakan upaya membentuk perilaku dan sikap seseorang yang didasari oleh ilmu pengetahuan, keterampilan sehingga setiap individu dapat memainkan perannya masing-masing. Proses pembudayaan terjadi dalam bentuk pewarisan tradisi budaya dari satu generasi kepada generasi berikutnya dan adopsi tradisi budaya oleh orang yang belum mengetahui budaya tersebut sebelumnya. Pewarisan tradisi budaya dikenal sebagai proses enkulturasi (enculturation) sedangkan adopsi tradisi budaya dikenal sebagai proses akulturasi (aculturation).

Kedua proses tersebut berujung pada pembentukan budaya dalam suatu komunitas. Proses pembudayaan enkulturasi biasanya terjadi secara informal dalam keluarga, komunitas budaya suatu suku, atau budaya suatu wilayah. Proses pembudayaan enkulturasi dilakukan oleh orang tua atau orang yang dianggap senior terhadap anak-anak, atau terhadap orang yang dianggap lebih muda. Sementara itu, proses akulturasi biasanya terjadi secara formal melalui pendidikan seseorang yang tidak tahu, diberi tahu dan disadarkan akan keberadaan suatu budaya, dan kemudian orang tersebut mengadopsi budaya tersebut.

Proses pembudayaan dapat dilakukan melalui internalisasi, sosialisasi, enkulturasi, difusi, akultuasi, dan asimilasi.

Pertama, internalisasi, dari segi bahasa ialah berasal dari kata kerja internalize, ...to make attitudes, fellings, beliefs, etc fully part of one's personality by absorbing them though repeated experience of or exposure to them, (Hornby, 1995: 624). Pandangan lain menyatakan bahwa "internalisasi adalah proses dengan mana orientasi nilai budaya dan harapan peran benar-benar disatukan dengan sistem kepribadian" (Johnson, 1986: 124). Lebih lanjut, internalisasi dapat dipahami sebagai proses pemantapan dan penanaman keyakinan, sikap, nilai pada diri individu sehingga nilai-nilai tersebut menjadi perilakunya (moral behaviour) (Rohman, 2012: 125).

Kedua, sosialisasi, secara luas sosialisasi dapat diartikan sebagai suatu proses di mana warga masyarakat dididik untuk mengenal, memahami, mentaati dan menghargai norma-norma dan nilai-nilai yang berlaku dalam masyarakat (Soerjono, 1982: 140). Menurut Goslin (Ihromi, 2004: 30), sosialisasi adalah proses belajar yang dialami seseorang untuk memperoleh pengetahuan, keterampilan, nilai-nilai dan norma-norma agar ia dapat berpartisipasi sebagai anggota dalam kelompok masyarakatnya.

Ketiga, enkulturasi, Koentjaraningrat (2003: 145) mengemukakan bahwa proses enkulturasi merupakan proses belajar dan menyesuaikan alam pikiran serta sikap terhadap adat, sistem norma, dan semua peraturan yang terdapat dalam kebudayaan seseorang. Effendi dan Setiadi (2006: 146) mengemukakan bahwa sejak kecil proses enkulturasi sudah dimulai dalam alam pikiran manusia, mula-mula dari lingkungan keluarga, kemudian te- 
Diterbitkan oleh Program Studi IImu Komunikasi

Universitas Ahmad Dahlan Yogyakarta

man bermain, lingkungan masyarakat dengan meniru pola perilaku yang berlangsung dala suatu kebudayaan. Karena itu, proses enkulturasi disebut juga dengan pembudayaan.

Keempat, difusi kebudayaan merupakan proses penyebaran unsur-unsur kebudayaan (ide-ide, keyakinan, hasil-hasil kebudayaan, dan sebagainya) dari individu satu ke individu lain, dari suatu golongan ke golongan lain dalam suatu masyarakat atau dari masyarakat ke masyarakat lain (Koentjaraningrat, 1990: 224).

Kelima, akulturasi, Kontjaraningrat (1990: 248), akulturasi merupakan proses sosial yang timbul apabila suatu kelompok manusia dengan suatu kebudayaan tertentu dihadapkan dengan unsur-unsur dari suatu kebudayaan asing dengan sedemikian rupa sehingga unsur-unsur kebudayaan asing itu lambat laun diterima dan diolah kedalam kebudayaan sendiri tanpa menyebabkan hilangnya kepribadian kebudayaan itu sendiri.

Keenam, asimilasi, menurut Koentjaraningrat (1990: 225) asimilasi merupakan proses sosial yang timbul bila terdapat golongan-golongan manusia dengan latar belakang kebudayaan berbeda-beda, saling bergaul secara intensif untuk waktu yang lama sehingga kebudayaan-kebudayaan golongan-golongan tadi masing-masing berubah sifatnya yang khas, dan juga unsur-unsurnya masing-masing berubah wujudnya menjadi kebudayaan campuran.

\section{Teori Perilaku Berkendara}

Perilaku dapat dipahami sebagai suatu tindakan yang konkrit yang ada pada diri manusia yang terwujud dari individu berupa suatu sikap dari anggota badan ataupun berupa ucapan secara spontan tanpa direncanakan atau dipikiran dan tanpa paksaan (Thoha, 2002: 11).

Perilaku yang disebut juga tingkah laku menurut Natawidjaja (1978: 16) adalah pernyataan kegiatan yang dapat diamati oleh orang lain dan merupakan hasil perpaduan dari pemahaman pengaruh-pengaruh luar dan pengaruh dalam. Kartono (1984: 3) menjelaskan perkataan tingkah laku atau perbuatan mempunyai pengertian yang luas sekali yaitu tidak hanya mencakup moralitas saja seperti berbicara, berjalan, lari-lari, berolah raga, bergerak dan lain-lain akan tetapi juga membahas macam-macam fungsi seperti melihat, mendengar, mengingat, berpikir, fantasi, pengenalan kembali, penampilan emosi-emosi dalam bentuk tangis atau senyum dan seterusnya.

Menurut Fishbein dan Ajzen (dalam Guritno, 1997; Ayuningtyas, Guritnaningsih dan Santoso, 2007) perilaku manusia dipengaruhi oleh pengetahuan, sikap dan niat. Adanya pengetahuan terhadap manfaat dari suatu hal akan menyebabkan seseorang mempunyai sikap terhadap hal tersebut. Kemudian sikap ini akan mempengaruhi niat seseorang untuk melakukan suatu kegiatan. Kegiatan yang dilakukan inilah yang disebut perilaku. Selain itu, sebagian besar dari perilaku organisme itu sebagai respon terhadap stimulus eksternal (Walgito, 2001).

Dalam paradigma perilaku sosial yang memusatkan perhatian antara individu dengan lingkungan sosialnya. Menurut Homan (dalam Ritzer, 1985) melalui teori exchange, bahwa terjadinya proses interaksi sosial timbul fenomena baru yang dapat diterangkan melalui pendekatan perilaku (behavioral), bahwa satu fakta sosial menjadi penyebab dari fakta sosial yang lain. 
Menurut Ali (1993:302) "kepatuhan hukum atau ketaatan hukum adalah kesadaran hukum yang positif. Sementara itu ketidaktaatan hukum padahal yang bersangkutan memiliki kesadaran hukum, berarti kesadaran hukum yang dipunyainya adalah kesadaran hukum yang negatif'. Kesadaran hukum masyarakat tidak identik dengan kepatuhan atau ketaatan hukum masyarakat itu sendiri. Hal tersebut dikarenakan kesadaran hukum yang dimiliki oleh masyarakat belum menjamin masyarakat tersebut akan mentaati suatu aturan hukum atau perundang-undangan (Ali: 1993:300).

Berkaitan dengan hal tersebut, Rahardjo (2006: 81), mendefinisikan sebab ketidakpedulian masyarakat terhadap hukum menjadi 3 (tiga), yaitu: “(1) kurangnya sosialisasi dari pemerintah mengenai peraturan yang ada, baik peraturan lama maupun yang telah disempurnakan (baru). Minimnya pengetahuan masyarakat akan hukum, juga merupakan salah satu penyebab pelanggaran hukum, (2) hukum yang saat ini dirasakan terlalu bersifat kaku sehingga masyarakat seolah-olah diperlakukan sebagai robot yang didikte dalam melakukan berbagai kegiatan.

Perilaku pelanggaran aturan lalu lintas didorong oleh sikap terhadap pelanggaran itu sendiri, sikap terhadap hukum/aturan lalu lintas, sikap terhadap polantas, yang tentu memiliki implikasi di tiga level individual, interpersonal, dan societal. Menurut Reason, Manstead, Stradling, Baxter, \& Campbell (dalam Junef, 2014: 54) bahwa tingkah laku berkendara yang tidak biasa (aberrant driving behavior) dapat dibedakan menjadi tiga jenis: (1) lapses; mewakili problem perhatian dan memori, umumnya dialami orang tua dan perempuan, kadang tidak berbahaya namun memalukan, (2) error; mewakili kegagalan observasi dan penilaian, seperti tidak melihat rambu/kendaraan lain, gagal belok, di mana tingkah laku ini lebih berbahaya dan semua pengendara mengalaminya, (3) violations mewakili tingkah laku berkendara yang beresiko dan dilakukan dengan sengaja, seperti mengebut dan menerabas lampu merah, di mana anak muda dan laki-laki cenderung lebih terlibat dalam tingkah laku. 
Diterbitkan oleh Program Studi Ilmu Komunikasi

Universitas Ahmad Dahlan Yogyakarta

\section{Perangka Pemikiran}

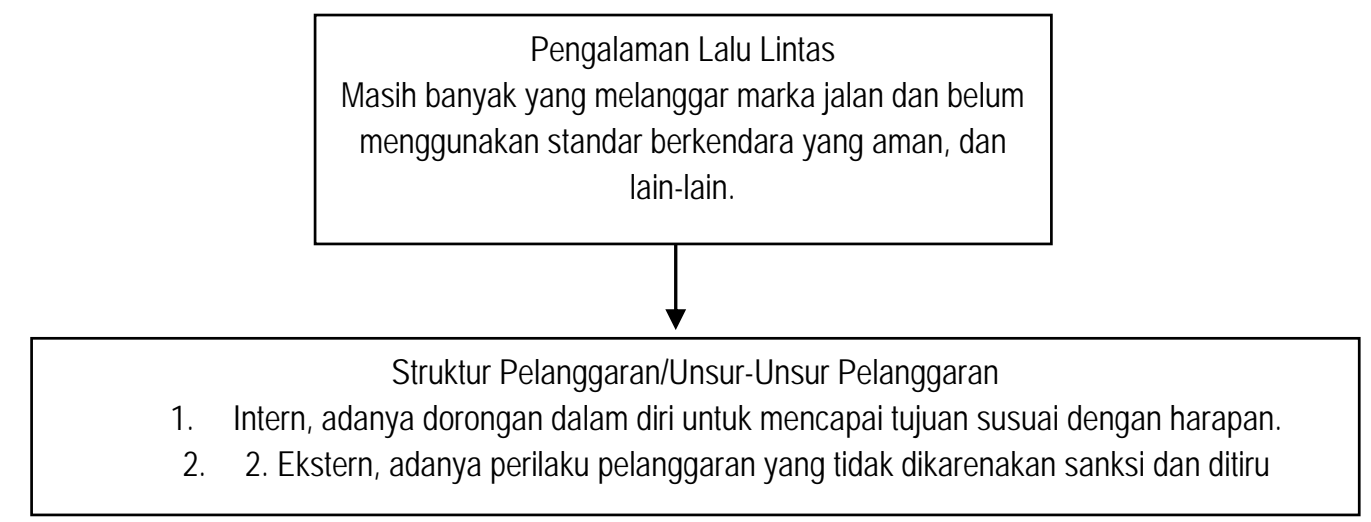

\begin{tabular}{|c|c|}
\hline $\begin{array}{c}\text { Sesuai dengan undang-undang nomor } \\
22 \text { tahun } 2009\end{array}$ & $\begin{array}{c}\text { Teori Planned Behavior, Teori } \\
\text { Interaksi Simbolik dan Teori Atribusi }\end{array}$ \\
\cline { 2 - 3 } & \multicolumn{1}{c|}{$\begin{array}{c}\text { Disiplin lalu lintas dapat dilakukan melalui } \\
\text { pendidikan formal, informal dan nonformal }\end{array}$} \\
\hline 1. Secara umum MASYARAKAT belum sadar hukum hal tersebut meskipun sudah mengetahui \\
2. $\begin{array}{c}\text { Terdapat hasil: } \\
\text { seraturan yang berlaku tetapi masyarakat masih enggan untuk melakukan disiplin berkendara. } \\
\text { cabang-cabang pendidikan formal. }\end{array}$ \\
\hline
\end{tabular}

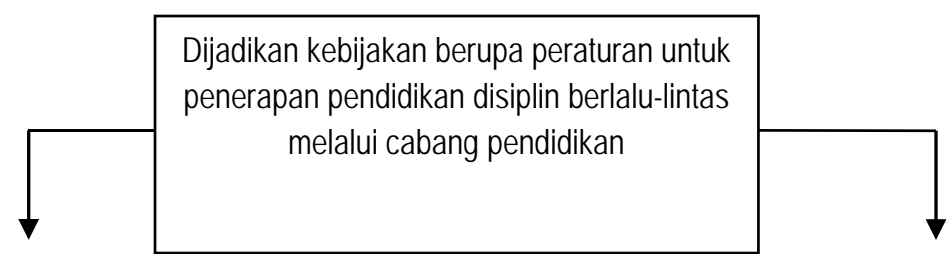

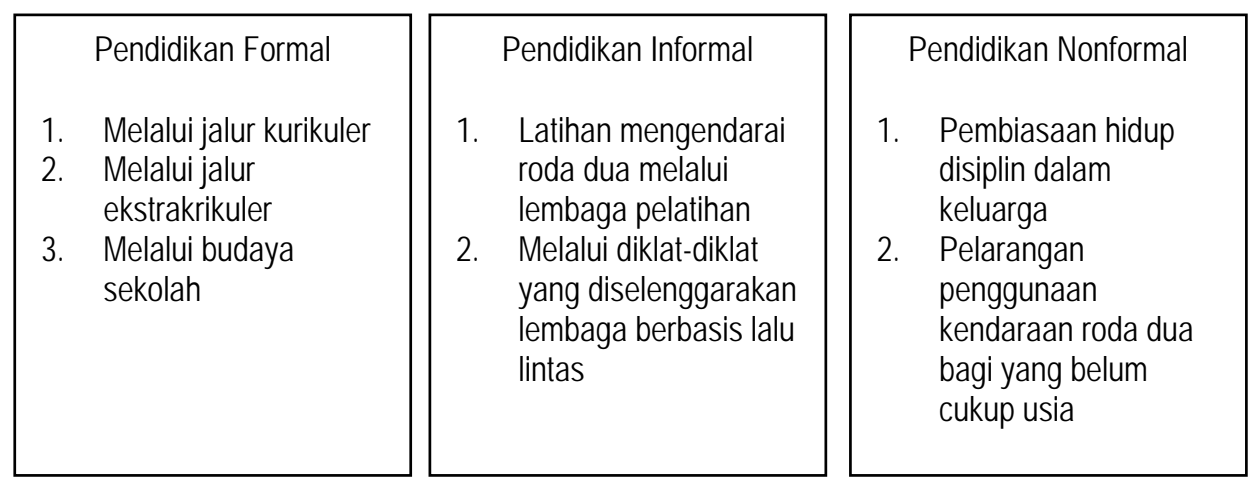




\section{HASIL DAN KAJIAN FENOMENOLOGIS}

\section{Faktor yang Mempengaruhi Pembentukan Budaya Disiplin Bekendara}

Dalam publikasi resmi UN WHO "Data systems: a road safety manual for decisionmakers and practitioners", mengutip Zero (2008), "Ambitious road safety targets and the safe systemapproach" dijelaskan bahwa sebuah sistem keselamatan (safe System) lalu lintas merupakan sebuah strategi dan pendekatan yang sangat efektif dalam menciptakan lalu lintas yang lebih selamat bagi seluruh pengguna jalan.

Mobilitas manusia dan barang dengan kendaraan bermotor berkembang begitu pesatnya, hal ini antara lain akibat peningkatan kesejahteraan dan kemajuan teknologi dibidang transportasi. Hal ini berdampak pada munculnya berbagai permasalahan lalu lintas berupa pelanggaran, kemacetan dan kecelakaan lalu lintas yang semakin meningkat dan kompleks dari waktu kewaktu apabila tidak segera ditangani dan diantisipasi.

Upaya yang dapat dilakukan memecahkan masalah disiplin dalam lalu lintas yaitu diperlukan pengendalian sosial (mechanism of social control), yang merupakan segala proses yang direncanakan maupun tidak direncanakan untuk mendidik, mengajak atau bahkan memaksa para warga masyarakat agar menyesuaikan diri dengan kaidah-kaidah dan nilainilai kehidupan masyarakat yang bersangkutan (Soekanto, 2007: 179).

Pengendalian sosial tersebut dapat dilakukan melalui pembudayaan disiplin sebagai sikap dan perilaku dapat dilaksanakan melalui pembinaan baik lewat jalur pendidikan formal, in-fomal maupun non-formal. Pendidikan formal dapat membiasakan disiplin melalui materi-materi yang terdapat dalam persekolahan dan kebiasaan-kebiasaan yang diberlakukan dalam situasi dan kondisi lingkungan sekolah. Melalui pendidikan in-formal, kedisiplinan dapat dilaksanakan melalui pelatihan berkendara yang baik dan benar sesuai dengan prosedur peraturan yang berlaku, dan dalam pendidikan non-formal dapat dilakukan melalui kedisiplinan yang dikembangkan dalam keluarga.

Dengan adanya pembudayaan melalui 3 (tiga) jalur pendidikan tersebut, diharapkan terjadi pergeseran perilaku disiplin berlalu-lintas masyarakat kepada arah yang lebih baik guna terciptanya suasana lalu lintas yang tertib dan nyaman. Selain itu, agar penelitian ini implementatif dalam menunjang pemberlakukan peraturan tentang berkendara, maka harus dikembangkan suatu model yang dapat mengakomodir semua permasalahan yang berhubungan tentang lalu lintas secara umum, khususnya yang terjadi di kota-kota besar.

\section{Budaya Disiplin Berlalu-lintas Kendaraan Roda Dua di Kota Bandung}

Dari uraian di atas, dapat ditarik simpulan sementara bahwa internalisasi disiplin berlalu-lintas di Kota Bandung belum berjalan dengan optimal. Hal tersebut disebabkan internalisasi baru berjalan pada tataran pendidikan formal terbatas belum menyeluruh. Keadaan tersebut diperparah dengan belum adanya lembaga pelatihan resmi berkendara roda dua dan kurangnya figur (teladan) masyarakat yang disiplin berkendara. Sehingga masyarakat tidak terlalu peduli apakah dirinya melanggar peraturan lalu lintas atau tidak, yang penting mereka bisa menguasai kendaraan dan berani mengendarainya di jalan raya dan saat di jalan raya mereka berprinsip bagaimana caranya agar sampai tujuan dengan tepat waktu. 
Diterbitkan oleh Program Studi Ilmu Komunikasi

Universitas Ahmad Dahlan Yogyakarta

Apabila merujuk pada keadaan tersebut perilaku disiplin sebagai modal utama dalam berlalu-lintas dipengaruhi oleh beberapa faktor, dalam penyesuaiannya perkembangan perilaku disiplin seseorang berbeda-beda. Subagya (2010), pendidikan berlalu-lintas ditekankan dalam upaya membangun karakter dan budaya berlalu-lintas yang aman tertib dan lancar.

Pertama, pendidikan, internalisasi disiplin sebagai sikap dan perilaku manusia dapat dikembangkan baik melalui jalur pendidikan formal maupun non formal.

a. Melalui pendidikan formal, dalam melaksanakan ketentuan dalam pasal 208 ayat (2) Undang-Undang Nomor 22 tahun 2009 tentang Lalu lintas dan Angkutan Jalan, Peraturan Gubernur Daerah Istimewa Yogyakarta No 54 Tahun 2011 tentang Pendidikan Etika berlalu-lintas pada Satuan Pendidikan, pasal 1 yang salah satunya berisi bahwa pendidikan etika berlalu-lintas adalah penanaman budaya tertib lalu lintas yang dimulai dengan pembiasaaan di satuan pendidikan

b. Pendidikan nonformal yang dimaksud adalah keluarga maupun intitusi sosial di masyarakat. Karena tidak terlepas dari itu, bahwa perilaku disiplin itu pada dasarnya mulai diterapkan di keluarga, mengingat suatu perilaku khususnya ditata secara baik dan terarah dimulai dari lingkungan keluarga, di mana orang tua membina dan mendidik anaknya agar memiliki perilaku yang baik salah satunya disiplin. Keluarga sebagai media merupakan alat yang paling efektif dalam pembiasaan perilaku sejak dini. Pada pelaksanaannya, harus ada dorongan yang kuat dan konsistensi dari orangtua agar anak mudah memahami dan dan melaksanakannya. Orang tua adalah sosok teladan yang akan diidentifikasi dan di internalisasi menjadi peran dan sikap oleh anak. Maka salah satu tugas utama orang tua ialah mendidik keturunannya dengan kata lain dalam relasi anak dan orang tua secara kodrati tercakup unsur pendidik untuk membangun kepribadian anak dan mendewasakannya, karena orang tua merupakan pendidik paling pertama dan paling utama bagi anak-anaknya (Kartono, 1992:59-60). Ki Hadjar Dewantoro (1962:100) menyatakan bahwa keluarga merupakan "Pusat Pendidikan" yang pertama kali dan terpenting karena sejak timbulnya adab kemanusiaan sampai kini, keluarga selalu mempengaruhi pertumbuhan budi pekerti tiap-tiap manusia. Di samping itu, orang tua dapat menanamkan benih kebatinan yang sesuai dengan kebatinannya sendiri ke dalam jiwa anak-anaknya. Inilah hak orang tua utama dan tidak bisa dibatalkan oleh orang lain. Bahkan Shochib (2000:3) menegaskan bahwa pihak yang harus berperan pertama kali dalam mewujudkan disiplin pada anak supaya tidak terbawa arus globalisasi adalah peran keluarga. Sekaitan dengan pendapat tersebut, narasumber yang berasal dari Kepolisian Sumur Bandung (Firmansyah, wawancara tanggal 14 Mei 2015), menegaskan bahwa yang menjadi masalah di Kota Bandung dewasa ini yaitu mudahnya orang untuk mendapatkan kendaraan bermotor. Dengan demikian terdapat tantangan yang dihadapi para orang tua yang memberikan kemudahan kepada anaknya untuk mengendarai kendaraan roda dua.

Pernyataan tersebut diperkuat oleh (Siswanto, wawancara tanggal 24 April 2015), yang menuturkan bahwa peran orang tua merupakan hal terpenting dalam mengawasi serta mendidik langsung anak-anaknya untuk mempersiapkan saat nanti wak- 
tunya untuk berkendara, tetapi banyak ditemui juga orang tua saat ini malah memberikan kebebasan pada anaknya untuk mengendarai motor.

Kedua, faktor Kepribadian. Faktor kepribadian banyak dikaitkan dengan pelanggaran dalam berlalu-lintas dan kecelakaan. McShane dan Glinow (2000:188) mengungkapkan bahwa big five personality dimention adalah lima abstrak dimensi kepribadian yang banyak disajikan oleh pendekatan kepribadian, yang terdiri dari conscientiousness, emotional stability, openness to experience, agreeableness, dan extroversion. Pervin, et.al. (2005: 292) mengatakan big five factor personality merupakan pendekatan teori faktor, di mana lima kategori faktor tersebut dapat dimasukan dalam emotionaly, activity dan sociability factor.

Ketiga, peranan Petugas Keamanan Lalu Lintas. Peranan para petugas merupakan hal yang menjadi mutlak dalam penerapan kedisiplinan sebagai pengawas maupun penegak para pelanggar lalu lintas di jalanan. Konsistensi para penegak hukum kunci dalam pembentukan perlaku disiplin, tanpa adanya konsistensi dari penegak hukum maka tata tertib lalu lintas hanya akan menjadi impian saja. Menurut Ancok (1995: 175-176) bila terjadinya ketidakdisiplinan pada masyarakat maka penyebab pokoknya adalah kurangnya petugas keamanan dalam menegakan hukum bagi si pelanggar, bukan karena lemahnya kesadaran masyarakat. Keadaan tersebut dungkapkan oleh hampir semua narasumber yang menjelaskan bahwa pengendara kendaraan roda dua akan disiplin dalam berkendara apabila terdapat polisi lalu lintas yang bertugas, apabila tidak ada yang bertugas maka keadaan lalu lintas kembali semberawut.

Hal tersebut terjadi dikarenakan masyarakat takut apabila dihadapkan dengan petugas yang pada akhirnya akan dikenakan sanksi apabila melangar aturan lalu lintas. Menurut Rahardjo (1993:15) penegakan hukum diartikan sebagai suatu proses untuk mewujudkan keinginan-keinginan hukum, yaitu pikiran-pikiran dari badan-badan pembuat undang-undang yang dirumuskan dan ditetapkan dalam peraturan-peraturan hukum yang kemudian menjadi kenyataan. Penegakan hukum bidang pencegahan, yang meliputi kegiatan pengaturan, penjagaan, pengawalan dan patroli. Di mana di dalam pelaksanannya tidak dapat dipisah pisahkan, karena merupakan suatu sistem lalu lintas untuk mewujudkan keselamatan tertib lalu lintas.

Dengan melihat penjelasn di atas, masyarakat pengguna kendaraan roda dua mempunyai harapan terhadap petugas dari Kepolisian maupun Dinas Perhubungan. Harapan tersebut diantaranya:

1. Ketegasan sanksi bagi para pelanggar

Sejumlah informan menyatakan harapan ketegasan penegak hukum dalam menindak pelanggaran yang terjadi di jalan raya, seperti pernyataan informan berikut:

"Kemacetan yang disebabkan di wilayah ini tentunya membuat para penegak hukum ekstra bekerja keras untuk menertibkan kondisi lalu lintas. Namun sepatutnya seorang penegak hukum yang melindungi dan mengayomi masyarakat mampu bekerja sama dengan masyarakat, di mana bagaimana pun penegak hukum memberikan pengertian yang cukup bagi pelanggar lalu lintas. Memperingati pengguna motor yang melakukan pelanggaran, bukan langsung menilang, dikhawatirkan saat terjadi penilangan terjadi 
Diterbitkan oleh Program Studi llmu Komunikasi

Universitas Ahmad Dahlan Yogyakarta

hal yang tidak pantas atau dengan kata lain "berdamai" dengan biaya Rp. 30.000 atau bahkan lebih. Hal tersebut yang dikhawatirkan saat para pengedara motor ditilang, tetapi malah "berdamai" dengan penegak hukum, jelas uang tersebut menjadi uang tambahan bagi penegak hukum bukan masuk pada kas negara, dan terlihat ketidaksenangan para masyarakat dengan penegak hukum seperti itu, sehingga dikhawatirkan kesalahan pengendara motor menjadi suatu hal yang dicari-cari oleh penegak hukum hanya untuk mendapatkan keuntungan semata" (Fauzan, wawancara tanggal 15 Maret 2015).

"Bagi mereka yang melanggar dapat "Berdamai" antara pengguna motor dengan penegak hukum sering sekali terjadi, hanya dengan Rp 50.000,- pelanggar dapat terbebas dari sanksi dan kembali melanjutkan perjalanan, berbeda dengan pengguna kendaraan bermotor yang melakukan pelanggaran di luar negeri, penegak tidak memberikan pilihan pada pelanggaran dan harus mengikuti sanksi yang berlaku, bukan malah "berdamai" (Aji Prasetyo wawancara tanggal 28 April 2015).

"Peran penegak hukum saat ini terus berupaya melakukan penindakan tegas dengan melakukan razia-razia di berbagai wilayah di Kota Bandung dalam upaya untuk meminimalisir pelanggaran-pelanggaran untuk menertibkan dan mendisiplinkan para pengendara motor. Hal tersebut menjadi hal yang sangat penting secara terus-menerus untuk melakukan tindakan bagi para pengendara nakal yang tidak membawa kelengkapan kendaraan maupun surat-surat izin berkendara....Namun niatan baik raziarazia yang dilakukan pihak penegak hukum harusnya tidak memunculkan anggapan bahwa banyak sekali terjadi "permainan" antara pelanggar dan penegak hukum untuk sama-sama hanya untuk memperoleh keuntungan semata, sudah sepatutnya sebagai pengendara motor harus lebih berhati-hati dan disiplin dalam berlalu-lintas untuk saling membantu pihak penegak hukum lebih ringan dalam menjalankan tugasnya" (Vebi Vebriansyah, wawancara tanggal 19 Mei 2015).

"Pihak penegak hukum untuk bersungguh sungguh dalam menindak pelanggar yang melanggar dan tidak menaati peraturan yang ada, bukan sekedar "cengli" ucap narasumber, harus tegas dan tanpa memberikan pilihan sedikitpun untuk melakukan tindakan yang tidak pantas sepertu sogok menyogok. Sehingga dapat terwujudnya ketertiban dalam berlalu-lintas dan budaya disiplin dalam berkendara" (Heru Setiawan, wawancara tanggal 19 April 2015).

"Penegak hukum dalam hal ini perlu lebih serius menangani permasalahan lalu lintas, bukan berarti permasalahan lalu lintas terjadi di pagi dan sore hari saja, karena penegak hukum di wilayah ini cenderung tampak saat jam berangkat kerja dan jam pulang kerja. Saat siang hari tiba, lalu lintas di wilayah ini kembali semberaut dan banyak pelanggaran yang terjadi, tentunya peran semua pihak menjadi hal terpenting untuk saling mengingatkan dan menghargai pengguba lainnya maupun penegak hukum" (Siswanto, wawancara tanggal 24 April 2015). 
2. Kebutuhan informasi dari petugas

Sejumlah informan menyatakan kebutuhan informasi dari petugas baik dari Kepolisian maupun Dinas Perhubungan, seperti pernyataan informan berikut:

"Jalan ini menyambungkan wilayah Bandung Timur dari Cicaheum Ujung Berung dan Cibiru. Kondisi jalan ini terdiri dari lajur kendaraan tanpa pembatas dan mulai lunturnya marka jalan yang ada, tentu membuat kebingungan pengendara motor dan cenderung malah membuat kemacetan di wilayah ini" (Fauzan, wawancara tanggal 15 Maret 2015).

Hal ini memang sangat sulit sekali dibenahi, di mana seharusnya baik wanita dan pria tentunya dalam berkendara harus benar-benar memahami tata cara baik mengetahui rambu-rambu dan keterampilan dalam berkendara itu sendiri, buka semata-mata hanya bisa mengendarai saja, tetapi saling menjaga keselamatan diri sendiri serta pengendara lainnya" (Heriman wawancara tanggal 25 April 2015).

3. Proaktif dari petugas

Sejumlah informan mengharapkan sikap proaktif dari petugas, seperti pernyataan informan berikut:

Informan mengharapkan adanya sikap proaktif dari petugas dinas perhubungan untuk membatasi jumlah kendaraan roda dua yang beredar di masyarakat untuk mengurangi pelanggaran lalu lintas.

"Permasalahan kepadatan pengguna motor ini menjadi hal yang harus di perbaiki guna membuat kenyamanan dalam berlalu-lintas, hampir secara mayoritas kendaraan yang berada di jalan adalah kendaraan-kendaraan baru. Membeli motor baru itu cenderung lebih murah, karena bisa melalui proses kredit, berbeda dengan membeli motor bekas, harus secara kontan. Hal tersebut membuat masyarakat tidak ragu untuk membeli kendaraan motor baru, dan setiap harinya kendaraan motor terus bertambah dan semakin membuat kemacetan tanpa adanya budaya disiplin dalam berkendara motor" (Fauzan, wawancara tanggal 15 Maret 2015).

"Ketidakdisiplinan pengendara motor dalam berkendara disebabkan karena terlalu banyaknya volume kendaraan yang ada di jalanan sehingga membuat para pengendara begiti banyak di jalanan dan membuat tingkat kesabaran para pengendara sulit dikendalikan karena kesal dengan kondisi jalanan yang semakin macet. Meningkatnya volume kendaraan di Kota Bandung tentunya tidak terlepas dari peran produsen yang menjual dengan mudah motor pada konsumen, cukup dengan DP ringan dan syaratsyarat mudah bisa memiliki motor yang baru" (Aji Prasetyo, wawancara tanggal 28 April 2015). 
Diterbitkan oleh Program Studi Ilmu Komunikasi

Universitas Ahmad Dahlan Yogyakarta

\section{SIMPULAN}

Pengalaman berlalu-lintas di Kota Bandung masih terdapat pelanggaran seperti pelanggaran marka jalan, tidak menggunakan helm, modifikasi kenalpot, pelepasan spion, pelepasan badan motor, menyalip dari kiri jalan dan sebagainya. Hal tersebut terjadi karena sikap pengendara roda dua selama berkendara masih muncul sikap yang negatif seperti sikap penerabas, hipokrit, ketidakjujuran, dan membeo.

Dalam rangka meminimalisir pelanggaran tersebut, pengguna kendaraan roda dua mengharapkan kepada petugas yang berwenang untuk tegas dalam memberikan sanksi kepada setiap pelanggar, terus memberikan informasi yang dapat menambah pengetahuan tentang bagaimana berkendara yang baik, dan proaktif dalam membatasi jumlah kendaraan roda dua yang beredar di masyarakat baik itu berupa kendaraan roda dua yang bodong maupun kendaraan roda dua yang tidak laik guna, dan petugas terus dituntut proaktif dalam memberikan sosialisasi kepada masyarakat tentang berkendara yang sesuai dengan peraturan yang berlaku.

Internalisasi disiplin berkendara roda dua di Kota Bandung selama ini baru terjadi pada tataran sekolah formal yaitu pada tingkatan Sekolah Dasar. Internalisasi disiplin berkendara roda dua di Kota Bandung diwujudkan dengan membangun hal-hal seperti berikut: 1) Sikap disiplin berasal dari latihan, pengendalian pikiran dan pengendalian watak yang dibangun dari sekolah. 2) Penanaman pemahaman yang baik mengenai sistem peraturan perilaku disiplin berkendara roda dua. Hal tersebut dilakukan dengan melakukan sosialisasi peraturan yang mengatur tentang lalu lintas di Kota Bandung seperti mengadakan sosialisasi ke sekolah dan razia kendaraan roda dua yang dilakukan bekerjasama dengan Dinas Perhubungan. Selain itu, salah satu cara yang telah di tempuh oleh Kepolisian Republik Indonesia yaitu kerja sama dengan salah satu stasiun televisi swasta dalam tayangan " 86 " untuk memberikan informasi berupa pemahaman yang baik mengenai sistem peraturan perilaku disiplin berkendara roda dua. 3) Sikap kelakuan atau perilaku yang secara wajar menunjukkan kesungguhan hati, untuk mentaati segala hal secara cermat dan tertib. Keadaan tersebut ditunjang dengan petunjuk berupa rambu-rambu lalu lintas yang jelas dan kuat akan sanksinya.

Model internalisasi disiplin berkendara di Kota Bandung dapat terjadi apabila semua unsur (orang tua, lembaga pendidikan, kepolisian, dinas perhubungan) bekerjasama untuk melakukan pendidikan disiplin yang terintegrasi. Dari pihak keluarga berupa pemberian dasar pemaknaan disiplin dalam kehidupan sehari; dari pihak sekolah yaitu memberikan sajian-sajian materi yang dikuatkan dengan kurikulum dengan penekanan disiplin berkendara; dari lembaga pelatihan yaitu memberikan masukan-masukan kepada kepolisian dengan ikut serta mengawasi pemberian lisensi berkendara dan memberikan masukan apaka seseorang masih memerlukan pelatihan atau tidak agar dapat menjadi pengendara yang baik.

Dari kepolisian yaitu memberikan sosialisasi peraturan penggunaan kendaraan roda dua yang baik, aman dan tidak menimbulkan kerugian bagi orang lain serta pemberian informasi sanksi apabila terdapat pelanggaran dalam penggunaan kendaraan roda dua; dan untuk dinas perhubungan yaitu dengan memberikan pelayanan berupa pemberian rambu 
yang tegas dan terbaca untuk semua pengendara misalnya dengan memberikan penjelasan di bawah tanda rambu seperti dilarang parkir dan sebagainya. 
Diterbitkan oleh Program Studi Ilmu Komunikasi

Universitas Ahmad Dahlan Yogyakarta

\section{DAFTAR PUSTAKA}

Anggarasena, B. 2010. Strategi Penegakkan Hukum dalam Rangka Meningkatkan Keselamatan Lalu Lintas dan Mewujudkan Masyarakat Patuh Hukum. Tesis pada Program Pascasarjana Universitas Dipenogoro. Tidak Diterbitkan.

Anggraini. D. 2013. Studi tentang Perilaku Pengendara Kendaraan Bermotor Di Kota Samarinda dalam E-Journal Sosiatri-Sosiologi, 1 (1), 10-19.

Ayuningtyas, D.S., Guritnaningsih, dan Santoso, A. 2007. Hubungan Antara Intensi untuk Mematuhi Rambu-Rambu Lalu Lintas dengan Perilaku Melanggar Lalu Lintas pada Supir Bus 01 Jakarta. JPS. 13 (1). 1-14.

Baron, R.A., and Byrne, D. 1991. Social Psychology. Understanding Human Interaction, Sixth Edition. Boton: Alyn and Bacon Inc.

Beninga, J. S. 1991. "Moral And Character Education In The Elementary School: In Introduction". Benninga, J.S. (Penyunting). Moral, Character, And Civic Education in The Elementary School. New York: Teachers College, Columbia University.

Boediningsih, W. 2011. Dampak Kepadatan Lalu Lintas terhadap Polusi Udara Kota Surabaya. Jurnal Fakultas Hukum. 20 (20). 119-138.

Budiarto, A dan Mahmudah. 2007. Rekayasa Lalu Lintas. UNS Press: Surakarta.

Chapin F.S. Jr. 1974. Human Activity Patterns and the City: Things People Do in Time and in Spice. Wiley. New York.

Chapin. F.S.Jr. 1974. Human Activity Patterns and the City: Things People Do in Time and Space Wiley, New York, hlm.9. Lihat juga D.J. Walmsky, Urban Living; the Individual in the City. John Wiley \& Sons: New York

Daeng, H.J. 2000. Manusia Kebudayaan dan lingkungan, Pustaka Pelajar, Yogyakarta 